\title{
When Brazil Got the Blues: The Diffusion of Blues in Brazil
}

\author{
Alan P. Marcus
}

\begin{abstract}
This article will examine the introduction of blues in Brazil (1985-1992), a phenomenon that has not yet been addressed in scholarly spheres until now. By highlighting the processes of globalization and the Brazilian blues band from Rio de Janeiro, Blues Etílicos, I ask what were the spaces, places, and venues that helped to disseminate blues throughout Brazil? How does an African-Americanbased genre adopted and popularized by upper-and-middle-class white urbanites in Brazil? To answer these questions, I discuss the process of globalization and the Geography of music, political, musical, and cultural backdrops, and the end of Brazil's military dictatorship in 1985, which overlapped with a major Brazilian rock festival, "Rock in Rio," and later, Brazil's first blues festival in Ribeirão Preto in 1989. This article adds to the scholarly literature of music geography by looking at ongoing discussions of Brazil's changing political, cultural, and musical landscapes.
\end{abstract}

\section{Resumo}

O foco aqui é compreender e examinar o fenômeno da introdução do blues como gênero musical no Brasil (1985-1992), nunca antes estudado em esfêras acadêmicas. Ao destacar os processos de globalização, e da banda de blues carioca Blues Etílicos, pergunto: quais foram os espaços, lugares e locais que ajudaram a disseminar o blues pelo Brasil? De que maneira um gênero de base afroamericana é adotado e popularizado por brancos urbanos de classe alta e média no Brasil? Para responder a essas perguntas, examino a Geografia da música e processos de globalização, cenários políticos e culturais, o fim da ditadura militar no Brasil em 1985, que coincidiu com um grande festival de rock brasileiro, "Rock in Rio," e o primeiro festival de blues do Brasil em Ribeirão Preto em 1989. Este artigo acrescenta à literatura acadêmica do blues e da geografia da música, observando as discussões em andamento sobre as mudanças nas paisagens políticas, culturais e musicais do Brasil. 
The blues as a musical genre, entered Brazilian musical landscapes at the tail end of Brazil's military dictatorship (1964-1985), overlapping the Reagan/Thatcher Era. However, it never gained a major entry into Brazilian musical mainstream, nor was it as popular for example, as the Brazilian northeastern-based Lambada craze of the 1980s, the mass global musical sensation. Nonetheless, this foreign-based musical genre gained a new musical category in Brazil, created by national record labels in the late 1980s -a "Brazilian 'national' blues" category, o blues nacional -which never existed before. In a land famous for its beaches, soccer, and the Amazon rainforest - how and when did the blues diffuse to Brazil?

In popular imagination, perhaps most people conceive of "Brazilian music" within the confines of samba, Carmen Miranda, or the celebrated songs by Tom Jobim, Vinicius de Morais, João Gilberto, and Roberto Menescal, for example, epitomized by Stan Getz' jazz interpretations of the swaying beats of Bossa Nova of the 1950s and 1960s. However, most people would probably be hard-pressed to imagine that blues has become a popularized musical genre in Brazil, and that it has produced dozens of its own well-known blues bands and musicians, with a loyal following and major blues festivals held annually, and several dozens of blues venues, bars, and clubs in virtually every Brazilian state (e.g.; Goiás, Mato Grosso, Maranhão, Rio de Janeiro, São Paulo, Sergipe, Piauí, Pernambuco, Amazonas, Paraná, Santa Catarina) ${ }^{1}$

Additionally, nightclubs and music festivals in Brazil have been named after the U.S. state of Mississippi, such as "Mississippi Blues Bar" located near the docks of Gamboa in Rio de Janeiro, and a blues festival with the same namesake in Caxias do Sul, Rio Grande do Sul, partially sponsored by the B.B. King Museum, Visit Clarksdale, Mississippi Delta Heritage Area, and Delta State University (Mississippi Delta Blues Festival, Brasil, 2020, https://mdbf.com.br). Websites in Brazil such as Blues' $n^{\prime}$ Jazz (https://bluesnjazz.com.br/web/) and Mandinga Blues (https://mandingablues.wordpress.com) devote their articles to blues and jazz news and venues in the country, and it is no wonder that journalists, Art Zantige from the Wall Street International Magazine, (2015) and Eugênio Martins Júnior (2009) have reported about the blues boom in Brazil. Evidently, given Brazil's hybrid, complex, and rich musical traditions, there is a disconnect here between the popular imagination of "Brazilian musical traditions" and "Brazilian culture" with the cultural mores and musical language of the blues.

This article aims to address this quandary. To the best of my knowledge, no scholarly work in the English language until now, has been written about the phenomenon of the introduction of

\footnotetext{
${ }^{1}$ A simple online search on Google for bares de blues no Brazil ("blues bars in Brazil") will show the geographical extent with maps of blues bars scattered throughout the country.
} 
blues in Brazil, despite a few brief overviews written by journalists. Therefore, the goal here is to fill this academic gap in Brazilian studies and music geography.

The strategy will be to first clarify the methodological and theoretical approaches used here. Second, I will briefly and broadly discuss the blues market as it dovetails with the phenomenon of the globalization of popular music. Third, to better understand the context of the introduction of blues in Brazil and its diffusion throughout the country, I will briefly look at the sociocultural and political environment in Brazil leading up to the first Brazilian blues festival in Ribeirão Preto in 1989 - a watershed moment for blues in Brazil -and then provide examples of Brazilian blues bands that emerged thereafter.

By the mid-1960s, popular music in Brazil had been influenced by, and or at least had incorporated some elements of rock and roll (i.e.; Beatles, Rolling Stones), and according to historian Bryan McCann, elements of blues as well, for instance, is the use of the "I-IV-V" blues bar (McCann, 2007). McCann cites blues influences such as the famed "blue note" broadly to address a few examples in Brazilian music. However, this does not mean that Brazilians had been playing the blues - far from it. ${ }^{2}$ In fact, Bossa Nova music (i.e.; and its iconic songs, for example, O Pato, Desafinado, or Garota de Ipanema) or the music of Eliana Pittman, Elza Soares, Dick Farney - to name a few artists who McCann brings up - popular in the late 1950s and 1960s among the Brazilian upper socioeconomic cohort, hardly fit into the musical genre universally recognized as "blues." That is, Bossa Nova and its musical and sociocultural frameworks (e.g.; composed from the upperclass, beachfront apartment views from Copacabana along Avenida Atlântica, or Avenida Vieira Souto in Ipanema) were worlds away from "blues culture" and from the musical landscapes of Robert Johnson, Muddy Waters, John Lee Hooker, or Howlin' Wolf for example, former cotton sharecroppers who in turn, had a specific tonality, instrumentation, with different musical and cultural languages and styles inherently tied to the African-American "Mississippi Delta blues world" or the "Chicago blues world." Among other Brazilian artists and bands, Tim Maia, Jorge Ben Jor, and later Ed Motta (Tim Maia's nephew) for example, were not blues musicians, despite being influenced by African-American funk and soul music. Also, Os Mutantes (with singer Rita Lee), Raul Seixas, and later Cássia Eller, were not blues musicians either; they were influenced mostly by early Anglophone rock and roll music from the 1950s or 1960s and emulsified them into their own respective Brazilian musical formats (I return to this discussion ahead).

\footnotetext{
${ }^{2}$ While I acknowledge that the shifting ground of the genre identity of blues with the frontiers and connections with other genres - jazz, R\&B, soul, and rock — are in fact fluid and not so rigidly demarcated, there are some basic characteristic differences (e.g.; musical phrasing, instrumentation, musical language, or song lyrics). One characteristic of the blues for instance, is the use of the "I-IV-V" blues bar and the "blue note" (e.g.; a musicial interval or the flattenning of the third or fifth note of a pentatonic scale).
} 
The period selected here (1985 to 1992) of course, was not arbitrarily chosen. The Beatles had arrived in the United States on the same year when the Brazilian military coup took place in 1964, a dictatorship that would last until 1985. Notably, 1985 was the year of the formation of one of Brazil's first blues bands from Rio de Janeiro, Blues Etílicos- and also the same year that marked the first massive rock festival in Brazil, "Rock in Rio." Therefore, 1985 was a critical year for Brazil in both politics and music, and this is the period of the incipient phase when Brazilian blues bands began to emerge-and when the "legitimate" genre of blues entered Brazilian musical market and landscape.

The year of 1992 was selected as the cut-off year here in this examination here, since by that year the blues boom had already materialized, and many Brazilian blues bands had already been signed by Brazilian record labels. Therefore, I do not examine the Brazilian blues movement after 1992. This examination is new, and since there is no scholarship available in the English language about the blues movement in Brazil or of its own blues bands, I have weaved secondary sources with vignettes, newspaper features, empirical evidence, personal communication with Brazilian blues artists, and my personal experiences during the early blues boom period in Brazil. ${ }^{3}$

What were the spaces (i.e.; venues) that helped to disseminate blues throughout Brazil? What band was the main disseminator of blues in Brazil? How does the geographic diffusion of an AfricanAmerican-based musical tradition of cotton sharecroppers in the U.S. South end up being adopted largely by Brazilian white urbanites? I answer these questions here by examining the genesis of blues in Brazil from the period of 1985 to 1992 and by taking a closer look at a Brazilian band from Rio, Blues Etílicos (the word Etílicos in Portuguese literally means "ethyl," loosely indicating "imbibing" or relating to "inebriation").

In summary, this brief synthesis does not include a discussion of all Brazilian blues bands/artists or venues, nor do I discuss Brazilian blues bands after 1992. I examine when and how blues was first introduced and popularized as a "legitimate" musical genre in Brazil between 1985 and 1992. Moreover, the focus here is to understand the processes of globalization and diffusion of the blues, and to examine the significance of the band, Blues Etílicos within the incipient Brazilian blues scene, and subsequently, how other blues bands in Brazil emerged after their popularity grew.

\footnotetext{
${ }^{3}$ It is important to acknowledge my posionality here. I was a very minor participant in the early Brazilian blues movement (1985-1992). I was the founder and guitarist of the Brazilian blues trio Blue Jeans (1986-1992). This band opened a few minor concerts in Brazil for other bands and artists such as Sugar Blue, Blues Etílicos, J.J. Jackson, André Christovam, Eduardo Dusek, Cássia Eller, Nuno Mindelis, and Itamar Assunção. The newly inaugurated MTV in Brazil had promoted a music video of a Blue Jeans' song, "O Cachaçeiro" (which I had written). However, until then the band remained unsigned to a record label with meek exposure. I permanently left the band and Brazil in 1992. I was then replaced by guitarist, Marcos Ottaviano, which was when the band was then signed to a local label and only thereafter gained national exposure. Therefore, this posionality here, may help to explain any biases or choices in the examples used here.
} 


\section{Brazilian Blues and Authenticity}

The introduction of blues in Brazil perhaps dovetails with the perception that "American musical traditions" (i.e.; folk, country, blues -ironically, which origins stemmed from the lowest socioeconomic U.S. demographic cohort) originate from a place that carries a strong or "high cultural cachet" as opposed to the perception that Brazil's national popular music carries low cultural capital (i.e.; the perception that Brazilian music that belongs to the povão: loosely translated as the "poor" or the "large populace," or "the masses"). That is, Brazilians suffer from a "Periphery Complex," and despite that MPB (Música Popular Brasileira, "Brazilian Popular Music") has long been tied to Brazil's nationalistic sentiments (Stroud 2016), the processes of cultural imperialism and the "Americanization" of Brazilian music (i.e.; introduction of funk, soul, rock, and singing in the English language) possibly stems from a long Brazilian obsession with U.S. culture, music and mores. The perception that Brazil was and is (and will always be) the "country of the future," has perhaps led many Brazilians to believe that by listening and/or playing música americana, "American music" they may have a chance to participate, imagine, and even belong to the "modern" world. However, playing music from a foreign country, sung in a foreign language, and from an alien culture, comes with its own predicaments. One of them, is the notion of authenticity.

Claudio Bedran, bass player of the Brazilian blues band Blues Etílicos, stated in a newspaper interview in 1989, that his band was not a cover band but that it "interpreted blues," he explained, "when we play Robert Johnson the arrangement changes, the beat is different, guitar solos are reinterpreted...nobody says that a symphonic orchestra is doing a cover of Bach" (Lima 1989 translation by author). This statement is perhaps loosely akin to what Connell and Gibson have to say, in that, "borrowing' was typical of all cultural forms, was creative, and additive, and little different from the situation where classical music was recorded and performed by national orchestras around the world" (2003, p.68). More importantly, and closely tied to this case of blues in Brazil, Connell and Gibson reflect on how authenticity "remains an intangible concept" (2003, p.27) and offer strategies to help understand this predicament of authenticity in music, "notions of authenticity derive from how music is valued, and the shifts in value that occur as music perceived to have been disembedded from its social and cultural origins" (2003, p.27). Connell and Gibson continue their discussion as they refer to the work of Grossberg (1992), who identified three dimensions to better understand the concept of authenticity, that is: "aesthetics (the skill and creativity of the artist), the construction of a rhythmic and sexual body (often linked to dance and black music); and the ability to articulate private but common desires, feelings and experiences, through a common language that constructs or expresses the notion of community" (quoted in Connell and Gibson, 2003, p.29). Therefore, they conclude that the idea of authenticity often blends with the perception of "credibility" (2003, p.44) - two important components here that are relevant to this discussion of blues in Brazil, as we shall see ahead. 
Comparisons (or perceived associations) made by Brazilian blues bands with the blues boom in Britain in the 1960s are often contentious in this context of "blues authenticity," given that blues musicians in both Brazil and Britain mostly comprised mostly of white, middle-and upper-class urbanites. In this case, one Brazilian musician once asked me, "if somebody like Eric Clapton from England can become a world blues icon, albeit worlds away from the livelihoods of black rural cotton-sharecroppers of the U.S. South, what prevents a Brazilian-born blues musician from becoming one as well?" While this is a valid question, however, the case of the British blues scene in the 1960s was unique and very different from the blues scenario in Brazil that occurred in the late 1980s, especially since blues has never been "indigenized" in Brazil as it was in Britain (See, Marcus 2020). The blues and folk boom in Britain in the 1950s (with its fascination with Skiffle and Lonnie Donegan) followed by the advent of a "British blues genre" in the 1960s (e.g.; with icons such as John Mayall, Eric Clapton, Peter Green, Jimmy Page, Jeff Beck, etc.) offer compelling clues to understand these differences, as I address next.

The first big difference between the case of Brazil and Britain, while obvious, is the language barrier and the cultural connections between Britain and the United States. That is, the transition of singing songs from "American musical traditions" (e.g.; blues, country, folk) was easier for British musicians to appropriate because of the English language in comparison to Portuguese-speaking Brazilians (that is, especially if audiences do not understand the lyrics sung in English). Second, British musicians had a sonic and cultural familiarity with American musical traditions that had stemmed from the old folk Irish, Scottish, and English ballads (that in turn, later influenced U.S.based folk and country music), and, from African-American blues tonalities introduced into Britain during and after the Second World War (Marcus, 2020). Brazil had neither of these historical backdrops, with no sonic ties to Anglo-American traditional musical folk styles from the British Isles, and no U.S. radio stations for U.S.-G.I.'s (e.g.; Radio Luxemburg, Radio Normandie) existed in Brazil during WWII like the ones available in Britain which played the music of Muddy Waters, Leadbelly, or Lonnie Johnson, for instance (Marcus, 2020).

That is, U.S. G.I.'s posted in Europe during WWII, listened to these radio stations that played U.S. records, and at the same time exposed Europeans to U.S. blues, jazz, folk, and country musical styles (e.g.; See, Marcus, 2020, and, Poiger, 2000, for the case of U.S.-based culture, jazz, and rock and roll in post-WWII Germany). For example, the British Skiffle craze with Lonnie Donegan at the helm in the mid-1950s, emerged out of this familiarity with blues, folk, and country traditions (musicial traditions which later influenced the Beatles and several other British bands), and thereby; a gamut of bands in the 1960s became known for their iconoclastic musical interpretations and known to U.S. audiences as "British Invasion bands" (e.g.; Marcus, 2020; Stratton, 2010). In Britain, the diffusion and popularization of blues evolved and shaped mainstream rock and pop musical spheres during the 1960s and 1970s with the worldwide success of British bands such as the Rolling 
Stones, Fleetwood Mac, Cream, Led Zeppelin, The Who, The Kinks, The Animals, The Faces, among others (Marcus, 2020). ${ }^{4}$ This musical engagement in Britain evolved in such a way, largely because the British had already become familiar with "American musical traditions" decades earlier in the 1940 s and 1950s - as a result of the processes of diffusion, and later, indigenization. ${ }^{5}$

Conversely, the Afro-Brazilian infused music produced several native-born hybrid musical genres in Brazil deeply connected to African musical traditions such as samba, MPB, frevo, forró, axé, brega, lambada, and pagode, among many other subgenres (stemming from the lowest socioeconomic cohort in Brazil - music by and for the povão) - however, they were completely different in terms of cultural context, in format, language, chord progressions, beat syncopation, tonality, and sonically from the iconic songs and sounds of the blues that emerged from the U.S. South, the Mississippi Delta, or Chicago for instance.

In several reports and advertisements that I found in Brazilian newspapers such as Revista do Disco, Diário de Notícias, and, Diário da Noite, from the 1930s to the 1950s, musical genres such as rumba, samba, bolero, waltz (valsa) are noted as coveted genres that were hugely popular in in Rio's socialite circles, casinos, and nightclubs of that time, and, notably where "swing" and "blues" were often lumped together as if they were one of the same, with an implied connotation of "high culture." Ostensibly, in Brazil "jazz" was synonymous with “blues." For example, Heloisa Helena, a Brazilian singer at the ritzy casinos of Urca, Copacabana, and Atlântico, curiously was advertised as a cantora de blues, "a blues singer" (she later became a Brazilian film and television actress). ${ }^{6}$ In the same newspapers, the records of Nat King Cole, Mel Tormé, Benny Goodman, Woody Herman, and Harry Belafonte records were advertised, as well as Brazilian radio (e.g.; Radio Ipanema) that was playing these records during the 1940s and 1950s, and while these artists may have been playing elements and derivations of blues albeit in traditional "jazz-istical" styles and instrumentations used in jazz (i.e.; brass instruments, piano, complex chords, and/or big bands), they were still not playing blues.

Also, for example, while Dick Farney, Eliana Pittman, and Elza Soares may have built their sounds upon jazz traditions, and, later, Raul Seixas, Os Mutantes, Rita Lee, and Cassia Eller (and Luís Melodia to a certain extent) were influenced by Anglo-American rock and roll from the 1950s and 1960s and were par excellence "rockers" (i.e.; influenced by Elvis Presley, and "British Invasion" bands such as the Beatles, Rolling Stones, the Animals, etc.) - however, none of them were playing blues music either (even if, of course, rock and roll is musically and closely related to blues). That

\footnotetext{
${ }^{4}$ Furthermore, Sean Stroud (2016) has discussed the vital dimension of the marketing benefit and the privilege of AngloAmerican artists singing in English in the so-called "international repertoire" category, as recording companies call it.

${ }^{5}$ Keep in mind that Brazil entered a period of virtual cultural and musical isolation during the military dictatorship, where foreign-made musical instruments and records were not allowed in the country, and media censorship was widespread.

6 "Revivendo o gosto do publico pela music argentina." Diário da Noite, March 28, 1941, p. 7.
} 
is, none of these artists and bands were utilizing instrumentations in a band format that are fundamentally characteristic to the musical language of blues. For example, the combination of the slide guitar (e.g.; "open G" tuning) in the traditional styles of Mississippi Delta blues guitarists; with the diatonic "blues harmonica" played with a Green Bullet microphone in the style of Little Walter; or singing blues minor/major tonalities- these were introduced to Brazilian audiences only after 1985. The band, Blues Etílicos was the first full band in Brazil to entirely commit to the enterprise of playing blues by implementing characteristic blues language as well as blues instrumentations, and the first band to be signed to a national record label as a "Brazilian blues band."

\section{Theoretical Backdrop}

To be clear, blues is a unique U.S-based musical genre - a cultural art form that emerged from the experience of African-Americans in the U.S. South, as Robert Palmer, explains, it is "a hybridized musical language that distilled the very essence of innumerable African vocal traditions" (Palmer, 1981, p.33). Blues was forged from African-based vocalizations, rhythmic syncopations, and musical traditions which became its musical foundation (the literature here is far too extensive to do it justice, however, for two good examples, see, Palmer, 1981; and Gioia, 2008) - it is a genre birthed in the U.S. South. However, despite its origins, blues was/is not calcified in time and place. For example, after the influx of millions of black Southerners during Great Migration to northern cities such as Chicago and Detroit, blues then became "electrified" with the advent of amplifiers for the guitar and harmonica, and drums (i.e.; the transition from "country blues" to "Chicago blues" for instance, as seen in the music of Muddy Waters and Howlin' Wolf, among others).

While musical and cultural studies have used various complex theoretical approaches to articulate the diffusion of blues and popular music, here my approach is deceptively simple: it is geographical. That is, the geographical diffusion of musical genres traverse across space and are adapted in different places, as geographers have already claimed (e.g.; Ford, 1974; Johansson and Bell, 2009; Marcus, 2020; Strait and Fujimoto-Strait, 2017). Therefore, understanding the movement of music across spaces and places and the processes of musical adaptation, becomes useful here to grasp how blues diffused to, and was popularized in Brazil.

In this case, it is important to highlight how scholars have discussed the important ties between globalization and music (Brandelerro and Pfeffer 2011), the importance of "music places" and "music spaces" (Alderman, 2001; Kruse, 2003) and identity and concert spaces (Kruse, 2010). For example, John Connell and Chris Gibson help to clarify adaptation processes, as they explain, "mobility is also responsible for performance types and musical spaces rebuilt in new circumstances as the result of flows of music, rekindling traditions or inspiring unexpected borrowings and appropriations" (2003, p.45). Moreover, Charles A. Perrone and Christopher Dunn discuss how 
hybridization, globalization, and cultural penetration in Brazilian music have played vital roles in these processes of music flows to Brazil (2001, pp. 2-3). Therefore, to understand the process of diffusion of blues to Brazil, the salience of movement and changes across space and time, and the impact of globalization are important dimensions to consider here, as I discuss next.

\section{Globalization and the Geography of Music}

The early propagation of blues in Brazil was conceived by a middle-and-upper-class white cohort, mostly from the urban centers in Rio de Janeiro and São Paulo-ironically, a genre that originally began by deprived African-Americans at the polar end of privilege and economic power. However, the idea that blues is played and listened largely by white musicians and audiences in Brazil, is hardly unique. In 2006, the Kitchens Group conducted a survey to examine the demographics of world blues fans for advertisers, showing that a disproportionate segment of the world's blues audiences is overwhelmingly white and over 40 years of age - estimated at over 80 percent of the total blues audience demographics (Making a Scene, The Independent Music Magazine 2020). This demographic is a telling commentary of the people who listen to blues and go to blues concerts today.

Today, Brazil is considered one of the top performing global markets for recorded music, making it the ninth largest market in the world with about 89 percent of Brazilians accessing music through on-demand streaming in 2015 (with the highest rate of growth in the 35 to 64 age cohort) (IFPI 2020, https://www.ifpi.org/consumer-research.php). The market for recorded music sales in Brazil grew by 18 percent between 2016 and 2017 (The Brazilian Federal Government, 2020a). Consequently, several major national music festivals with several genres take place throughout Brazil, ranging from rock to country and Brazilian sertanejo (a Brazilian-based rural musical genre) and that attract thousands of attendees yearly. For example: Rock in Rio, Lollapalooza (in Rio), Meca Love Recife (in Pernambuco) and Fazenda Pontal (in Rio Grande do Sul), Bananada (in Goiás), Festa do Peão de Barretos ("Barretos Cowboy Festival” in Barretos, São Paulo), and Caldas Country Garanhuns Winter Festival, (in Pernambuco) among many others (Brazilian Federal Government, 2020b). However, it also important to keep in mind that most of the Brazilian music industry is still controlled by four major music labels: Warner, Sony BMG, Universal, and Som Livre/EMI (Mello, 2012).

The diffusion of blues to Brazil is not unique either in terms of broader discussions of the globalization of music (e.g.; Perrone and Dunn, 2002). For example, blues festivals are held in India (Mumbai) and even in Nepal (Kathmandu), and blues festivals have for a long time been well attended throughout countries in Europe (e.g.; Switzerland, Denmark, Sweden, U.K., Ireland, Spain, Poland, Netherlands, Germany, France, Italy), and Latin America (e.g. other than Brazil -Mexico, 
Argentina, Ecuador, Peru, Chile, Belize, Panama) as well as in Australia, New Zealand, and Canada. There are blues venues (i.e.; bars, clubs, and concert halls) well-known throughout the world (including in Japan), and blues publications for example, in the U.K. (Blues Matters, Blues in Britain), France (ABS Magazine, Blues \& Co, Blues Magazine), Austria (Concerto Magazine, Blues Art Studio), Poland (Blues in Poland), Netherlands (Block Magazine), Belgium (Rootstime), Italy (Il Popolo del Blues, Blue City, Roots and Blues), Finland (Blues News), and Spain (La Teberna del Blues) (e.g.; see, Terra Blues, 2020, https://www.terrablues.com/bluespublications.html). The extent and range of the geographies of festivals and publications speaks volumes to the spread and diffusion of blues worldwide - and to the globalization of blues.

The Blues Foundation based in Memphis, Tennessee, whose mission is to "preserve blues heritage, celebrate blues recording and performance, expand worldwide awareness of the blues, and ensure the future of this uniquely American art form" (The Blues Foundation, 2020, https://blues.org/about/\#mission), counts on over 200 affiliated blues societies and 4,000 members around the world, including the Korea Blues Society and Israel Blues Society (e.g.; Blues Foundation map, https://blues.org/affiliate-map). Clearly therefore, we can see that the geographic diffusion and impact of blues as a popular musical genre across the world, is broad.

This phenomenon of these processes of diffusion of other popular music genres and their popularization around the world should also be considered. For example, Melissa Ursula D. Goldsmith and Anthony J. Fonseca edited an encyclopedia of hip-hop around the world, with coverage in 140 countries (2019). ${ }^{7}$ In a different example, Jeremy Wallach, Harris M. Berger, and Paul D. Greene (2011) edited a volume about Metal music ("heavy metal”) around the world. Its popularity is examined in countries ranging from Indonesia, Easter Island, Japan, China, Malaysia, Singapore, Nepal, India, Israel, to Slovenia, Malta, Norway, Brazil, and Canada.

Likewise, blues has undergone the process of diffusion through many means, globalization being the most imporant and recent one, spreading from the United States to various parts of the world, often with hybrid outcomes by the incorporation of local elements while at the same time, remaining loyal to its musical integrity. The diffusion of blues and rock and roll to Britain probably more than any other country (e.g.; Brocken, 2003; Carosso, 2013; Frame, 2007), however; its diffusion to other countries has also been examined in Germany (Adelt, 2010), Russia (Urban, 2004) - and now, in Brazil.

\footnotetext{
${ }^{7}$ Furthermore, rap and hip hop are hugely popular in Brazil -particularly in favelas, notably the baile funk. Here "funk" does not necessarily mean the same as the traditionally known U.S.-based funk musical genre, but rather refers to the location where the dances take place in general (it is largely a misnomer). That is, "the music of choice in the favelas is 'Rio funk.' A hard-edged dance style of screeching rap and booty-shaking beats, this is the bastard child of Miami bass, which arrived here in the mid-1980s and went native" (Bellos, 2005).
} 
In Russia, for instance, the Bliuzmen ("Bluesmen") produced a foreign-domestic hybrid (Urban, 2004). Michael Urban explains "blues as a popular idiom has relied on direct and earthy language to reach its audience, articulating those truths that resonate in the everyday consciousness of everyman; yet in Russia it is sung almost exclusively in English, which both performers and their audiences rarely understand" (2004, p.xiv) - an avenue to an imagined "modernity" that is closely related to the popularity of blues in Brazil.

Morevover, Urban continues, "although blues has its origins in the 'low' culture of the African American South, it has been transformed in Russia into an object of 'high' culture" (2004, p.xiv). This is a reference to the cultural capital gained through attending or participating in art of "high culture" of course in opposition to art that is considered and looked down as "low-brow." Consequently, in both Russia's post-Soviet-era blues boom - and during Brazil's post-militiary dictatorship-era as well - blues has "appeared as an avenue to an imagined modernity" (Urban, p. xiv). Therefore, the political and cultural climates in Brazil preceding 1985, are important facets to consider in this diffusion process, discussed next.

\section{Brazilian Political and Cultural Climates}

Now that I have briefly discussed a few of the processes in which music expands geographically, and before I answer the question "how and when did Brazil get the blues?" a succinct discussion of the political and sociocultural backdrop in Brazil is necessary. Moreover, to answer this question effectively, it is important to at least, briefly describe the changes that occurred in Brazilian social and political spheres in the 1980s.

Brazil did hold its own popular musical festivals, for example, the Festival Internacional da Canção ("The International Song Festival”) (1966-1972), televised by the Brazilian television giant conglomerate Rede Globo, and held at Maracanãzinho, propelling the famous left-wing, antidictatorship song, Pra não dizer que não falei das flores ("Not to Say that I haven't spoken about the flowers") by Geraldo Vandré, as well as the participation of Brazilian musical icons such as Chico Buarque, Milton Nascimento, Tom Jobim, and Vinícius de Moraes. ${ }^{8}$ These Brazilian festivals, however, were hugely dissimilar (musically) to the festivals that celebrated the renaissance of African-American blues icons who performed at Newport Folk Festivals during the late 1950s and early 1960s for example (i.e.; Mississippi John Hurt, Gary Davis, Sonny Terry and Brownie McGhee,

\footnotetext{
${ }^{8}$ Leading up to the end of military rule in 1985, musical landscapes in Brazil were notably unique (e.g.; Tropicália, MPB, Jovem Guarda). Of course, there are far more complex nuances to include, and I have not attempted to address them here to do it justice (For a detailed discussion on those musical landscapes and counterculture in Brazil, see, Dunn 2016).
} 
Muddy Waters, etc.). Nor did they resemble U.S.-or-British music rock festivals of the same period such as Monterey Pop Festival (1967), Woodstock (1969), and the Isle of Wight (1970), attended by the well-known counterculture audience and their bedraggled appearance, with a line-up of AngloAmerican blues and rock icons -most of them unknown in Brazil beforehand, for example, Jimi Hendrix, Janis Joplin, The Who, Canned Heat, Johnny Winter, Mountain, and Santana - and who would only become known to most Brazilian audiences well after 1970, markedly after the deaths of Hendrix, and Joplin. In fact, when Brazilian singer and icon Rita Lee of Os Mutantes (and later, Tutti Frutti) was asked by the Brazilian national magazine Manchete about Janis Joplin, she answered: Quem? Janis Joplin? Não Conheço. Quem é? (“Who? Janis Joplin? I don't know her. Who is she?"). Moreover, Joplin visited Rio in early 1970 (just months before she died), joined in Rio's Carnaval, and visited Brazil's northeastern beaches, yet remained unrecognized by most Brazilians. Joplin ostensibly only gained popular attention in Brazil mostly after her widely covered death (as featured in Manchete magazine throughout 1970). ${ }^{10}$

Hence, the Brazilian music festivals of the late 1960s and early 1970s catered to a left-leaning Brazilian young middle-class audience and, more importantly, artists were monitored and censored by the Brazilian government, media, and the television conglomerate, Rede Globo which covered the festivals (i.e.; despite the lyrics of a few songs that often contained double-entendres used to subtly criticize the military dictatorship) (e.g.; see, Dunn 2016).

By the end of Brazil's military dictatorship in 1985, Tancredo Neves was elected the first civilian to be democratically elected president since 1963, but he died before his inauguration took place. José Sarney was sworn in as president, and inflation rates approached 300 percent, and surpassed 1,000 percent in the late 1980s, and in a whirlwind of Brazilian political scandals and economic downturns, Brazilians experienced a series of major political and social changes throughout the late 1980s. Despite the economic turmoil, by the end of the military dictatorship in 1985, a political and cultural "opening" and a sense of change emerged. At least, it appeared that way at the time.

Altogether, the economic, social, and political circumstances and turmoil leading up to the 1980s in Brazil, help to explain why only white urbanites from middle-and-upper social classes, were the ones who had most of the exposure to blues music proper. Moreover, they had access to instructional/musical books about blues instrumentation (e.g.; specific guitar slide techniques and tunings, or the access to purchase a Green Bullet harmonica microphone), by virtue of having the socioeconomic privilege to travel to the United States or England (i.e.; as tourists or as students), or

\footnotetext{
${ }^{9}$ Manchete. Rio de Janeiro, October 3, 1970, 18 (963), p.105.

${ }^{10}$ See, for example, Manchete. Rio de Janeiro, October 3, 1970, 18 (963).
} 
to purchase imported records, good electric amplifiers, or musical instruments sold in Brazil at exorbitant prices. The fact that a handful of white, urbanite, middle-and upper class youth were the first blues enthusiasts in Brazil is a prime example of hierarchical diffusion (for a context on race and social class in Brazil, see, Marcus 2013).

\section{The Catalyst Event: Ribeirão Preto}

The catalyst of the blues boom in Brazil was unquestionably in 1989, with the country's first blues festival held in Ribeirão Preto (in the interior of the state of São Paulo, about four hours by car from the city of São Paulo) at the Cava do Bosque Arena. This was the pivotal event that introduced U.S. and national blues artists to a wider Brazilian audience- despite a very small pre-existing Brazilian blues fan-base. Since 1989, that town has held seven more blues festival events, and the local press has capriciously dubbed Ribeirão Preto the "capital of Brazilian blues" for no other reason other than it was the location of Brazil's first blues festival.

Organized by promoter, César Castanho, the first blues festival included two important Brazilian blues representatives, Blues Etílicos and André Christovam, who were among the highcaliber line-up consisting of U.S. blues icons such as Buddy Guy, Junior Wells, Albert Collins, Etta James, Debbie Davies, and Magic Slim. Otávio Rocha, slide guitarist for Blues Etílicos, explains that moment, "it was as if we had met Jesus and the apostles" as he describes his nervousness of meeting those famed blues icons (personal communication, Otávio Rocha, March 19, 2020). This festival clearly raised awareness of the blues as a genre as well as it marketed and exposed Blues Etílicos to Brazilian audiences, many of whom had not yet heard of them outside of Rio.

Notably, during that festival, a random audience member had communicated to me that he was expecting the musicians to play "jazz-like" music (i.e.; "smooth and easy listening") - which is hardly what he heard of course, with the fiery and thunderous performances of Buddy Guy or Albert Collins, for example. ${ }^{11}$ Blues records had not been commonly played on most Brazilian national radio stations yet, and Brazilian audiences were still unfamiliar with the genre. In other words, it was clear: before the festival, blues was an alien cultural product to most Brazilians - historically, geographically, and musically. For perspective, Buddy Guy and Junior Wells had performed three years earlier at the 150 Night Club at the ostentatious Maksoud Plaza Hotel in downtown São Paulo, performing in black-tie, for a small, wealthy, over-40 crowd that was disconnected on many levels

\footnotetext{
${ }^{11}$ In 1989, I worked as an intern for a marketing and publicity agency firm that was hired to promote that blues festival, and I oversaw the selection of video clips and songs that were going to be used later in advertisements on local and national television and radio. The agency sent me to the festival at Ribeirão Preto for the week.
} 
(i.e.; sociocultural, economic, racial) from the music and from the musicians. Clearly, there was a cognitive dissonance here. However, that perception of blues would soon change.

At that time of this festival, many Brazilians still thought that blues was in fact, "jazz," and, that rock and roll (e.g.; Elvis Presley, the Beatles, the Rolling Stones, etc.) was something else entirely divorced from blues, evidently an erroneous assumption (perhaps a distorted assumption made by Brazilians that somehow rock and roll was equated with "whiteness," and that blues and jazz with "blackness"). Here we find yet another example in Brazil of how "jazz" had become synonymous to "blues." Therefore, blues was perceived at that time as "cocktail-lounge music" to be played with its complex dissonant chords "quietly" at nightclubs frequented by socialites - a musical genre that was clearly not made for the Brazilian povão. Consequently, we return to an ironic twist here - that there was a cultural cachet to be gained with this new appreciation of blues. Therefore, similar to the case of blues in Russia, in Brazil blues bands are likely to be found in "refined and sofisticated nightspots" (Urban. 2004, p.iii).

A few years earlier, also coinciding with the end of the military dictatorship in Brazil, Brazilian rock bands received a major boost in 1985 - and Sean Stroud (2016) has dubbed it, the "Rock in Rio Factor." He points to the resulting aftermath of the huge outdoor concert, "Rock in Rio," held on January 1985, attracting a total of 1.4 million attendees (for the week), a world record for a single event then (See, Stroud 2016). ${ }^{12}$ There were no blues artists in the line-up of the first Rock in Rio that year.

However, that would also change quickly. By 1991, Flávio Guimarães, harmonica player for Blues Etílicos, would perform at the "Rock in Rio II" playing harmonica for Brazilian rock artist, Paulo Ricardo to an audience of 150,000. By 1992, Otávio Rocha, slide guitarist also for Blues Etílicos, followed by performing with Midnight Blues Band, headed by Roberto Frejat and his celebrated band from Barão Vermelho at the "Hollywood Rock Concert," with equal amount of exposure (personal communication, Otávio Rocha, March 19, 2020). It is here in this context of the marketing efforts to promote blues in Brazil, and the larger exposure of blues to Brazilian audiences, that I discuss the band Blues Etílicos next.

\footnotetext{
${ }^{12}$ The international acts at "Rock in Rio" over the course of the week, ranged from Queen, Rod Stewart, AC/DC, Whitesnake, to James Taylor, George Benson, and Al Jarreau. Brazilian acts included Ney Matogrosso, Erasmo Carlos, Alceu Valença, Eduardo Dusek, Rita Lee, Elba Ramalho, Lulu Santos, Os Paralamas do Sucesso, Blitz, and Barão Vermelho.
} 


\section{The Catalyst Brazilian Blues Band: Blues Etílicos}

Blues Etílicos emerged as the first Brazilian band to fully devote themselves to blues-a quintet comprising Flávio Guimarães (harmonica, vocals), Greg Wilson (guitar, lead vocals), Otávio Rocha (guitar, and slide guitar), Claudio Bedran (bass), and Beto Werther (drums)(the original drummer was Gil Eduardo until 1994). The band was formed in 1985 with their first gig at the bar, Viro do Ipiranga, in the neighborhood of Laranjeiras, Rio. In 1987, their first LP self-titled, Blues Etílicos, was released by Satisfaction, an independent label in Rio (managed then by Renato Arias, who also owned a record store in Rio with the same name). By 1989, they were signed to Eldorado (a national Brazilian label) and released Água Mineral that same year, and a year later they released San-Ho-Zay (1990), which sold 35,000 copies - which for the Brazilian blues market, is considered to this day, the best-selling album ever for a national blues band.

Since 1992, they have played at every major blues festival in Brazil and have performed live on major Brazilian television channels (e.g.; TV Manchete, TV Cultura, and Brazilian MTV). Pedro Strasser entered the band in 1994 but left in 2017, when Beto Werther became the permanent drummer (former member of another Brazilian recording blues band, Big Allambik).

Blues Etílicos would gain momentum during the late 1980s and throughout the 1990s, with its faithful fan-base and its well-attended live concerts exemplifying the process of contagious diffusion. They also began to perform at venues and clubs outside of Rio de Janeiro, notably in the states of São Paulo, Santa Catarina, and Paraná. For example, they performed in 1995 for an audience of 30,000 in Florianópolis. As Otávio Rocha explains, they were never part of the mainstream or "underground music scene" in Brazil, since the press dubbed them simply as a blues band, yet they were always playing "blues/rock." More recently the band has fused their music with traditional rural Brazilian music, making important inroads into a hybrid music better known today as "world music."

The band has made a concerted effort to incorporate the musical vernacular of blues with traditional Brazilian musical elements (clearly seen with the introduction of an Afro-Brazilian instrument of Bahia, the berimbau in their song, Dente de Ouro). More recently, they have released an album, Canoeiros, with Sertanejo musician Noel Andrade (from Franca, interior of São Paulo), incorporating elements of the blues musical language with traditional Brazilian musical formats of Sertanejo (traditional rural music developed from the agricultural peasantry in the rural interior of the states São Paulo, Minas Gerais, and Goiás) (personal communication with Otávio Rocha, March 19, 2020).

Moreover, since the 1990s, Blues Etilicos members have cross-pollinated their music with Brazilian musicians engaging in their own individual musical projects. For example, Flávio Guimarães (a former student of Brazil's eminent Brazilian harmonica player, Mauricio Einhorn) has

ßRASILIANA: Journal for Brazilian Studies. ISSN 2245-4373. Vol. 10 No. 2 (2021). 
participated in recordings with various Brazilian musical artists. ${ }^{13} \mathrm{He}$ is considered the pioneer in using the diatonic harmonica ("blues harp") in Brazil.

It is important to point out that the band formation consisting specifically of a blues harmonica player and a slide guitarist together with a rhythm guitar, bass, and drums, was never seen before in Brazil. That is, Rocha and Guimarães were the first to integrate the slide guitar and the blues harp in a band format into Brazilian musical spheres. No Brazilian artist or band before them (not Raul Seixas, Luís Melodia, Celso Blues Boy, Tutti Frutti, Os Mutantes, etc.) integrated these instruments in a permanent band format, and in the specific context of blues musical language into their songs. Finally, every other album released by Blues Etílicos (with the exception in just two albums) includes song lyrics in Portuguese as well as in English. On that note, guitarist and vocalist, Greg Wilson who has released two solo albums, was born in Tupelo, Mississippi (birthplace of Elvis Presley), and moved to Brazil as a young child with his parents who were Methodist missionaries. This helps to explain Wilson's singing style in English without a "foreign accent" with a conspicuous U.S. Southern accent.

During the late 1980s, the band would typically perform to a swarm of attendees who would cram into small clubs and bars to catch a glimpse of this "new" blues music played by white carioca urbanites. The crowds increased in size, and soon they were performing at large venues and television specials throughout Rio and the rest of that country, as well as Paraguay and Argentina. Evidently, there was a high demand for that style of playing blues music in live venues.

So, why did the Blues Etílicos become so popular? It is likely that their popularity grew as they were the first full band to convey convincing interpretations of blues in Brazil by keeping true to the integrity of the genre, and in line with the notion of "authenticity" discussed earlier, which was new in Brazil. I am not claiming here that what they were doing was revolutionary new, even if they were writing their own material, however, the difference between other Brazilian blues bands and Blues Etílicos, was that the latter used their instruments, fundamentally characteristic in the blues language, and combined them into the integrity of their music (slide, harmonica, guitar, tonality, vocals) - which no other recording Brazilian band had used in a full band unit until then.

In addition, at a time when younger audiences of the 1980s were largely dissatisfied with the music of this period, Blues Etílicos managed to also effectively revive an interest in the music and counterculture period of the late 1960s by emulating the sounds of bands such as the Allman Brothers, Rory Gallagher, or Johnny Winter for instance- which perked the interest of a younger

\footnotetext{
${ }^{13}$ For example, with Alçeu Valença, Almir Sater, Djavan, Cássia Eller, Ed Motta, Erasmo Carlos, Fernanda Abreu, Frejat, Gabriel O Pensador, Leo Gandelman, Luiz Melodia, Paulo Moura, Paulo Ricardo, Renato Russo, Rita Lee, Titãs, Yamandu Costa, Zeca Baleiro and Zélia Duncan
} 
audiences who were largely unfamiliar with those bands. That is, while remaining loyal to the integrity of the blues, they also incorporated musical elements of blues/rock of the late 1960s and early 1970s.

Although Rio is their hometown, which included important venues such as Jazzmania and Circo Voador, the city of São Paulo became the central place that helped propel and disseminate the band's music and the blues genre-for instance, it was the base for their record label, Eldorado and other important venues such as the Centro Cultural ("Cultural Centre"), Aeroanta, and Dama Xoc (personal communication, Otávio Rocha, March 19, 2020). The jazz club, St. Germain (popularly known as "Sanja") in São Paulo, was a small venue for jazz and jazz/fusion, but at that time (pre1992), none of the Brazilian blues bands played there.

Blues Etílicos performed frequently at a venue in Rio known as the Circo Voador (literally, "Flying Circus," which closed in 1996, and then reopened for a short time in 2004). In 1995 and 1996 the band had a record attendance for all times at that venue (with a featured appearance of Brazilian soul singer Ed Motta-the nephew of eminent Brazilian artist, Tim Maia). The Circo Voador was conceived in 1982 as a cultural space, became their launching pad to developing a steady loyal fan base for the band. Local newspaper advertisements for this venue included no number for its address (it was simply addressed in the newspapers as "Arcos da Lapa. s/n," meaning "Arcos da Lapa, no number"). Located in the neighborhood of Lapa in the center of the city, "Lapa Arches," and also known for being the cradle of bohemian Rio. In this context, it is also important to note that Rio had become "the epicenter of the Brazilian counterculture in the early 1970s" (Dunn, 2016, p.47).It was essentially a huge circus-like tent that covered a stage for performances (maximum capacity was approximately 3,000 people). Consequently, its bohemian neighborhood legacy, dovetailed with the mindset reminiscent of the late 1960s/early 1970s counterculture movement- a far cry from the audiences seen at blues performances for Junior Wells and Buddy Guy at the 150 Night Club at the Maksoud Hotel a few years earlier in Sao Paulo.

Keep in mind that in 1990, there were only three Brazilian blues bands who were signed to record labels in Brazil: André Christovam, Blues Etílicos, and Celso Blues Boy. ${ }^{14}$ However, there were a handful of non-recording Brazilian blues bands (mostly from São Paulo and Rio de Janeiro) following the footsteps of Blues Etílicos and with the boost from the Ribeirão Preto blues festival, and who had been performing at small local venues in the southeast region of Brazil, for example,

\footnotetext{
${ }^{14}$ Celso Blues Boy (b.1956-d. 2012) was the most prominent of the three, with national name recognition. While his namesake indicates his connection to blues music, his real name was Celso Ricardo Furtado de Carvalho. He died in 2012 of throat cancer, having released 11 albums between 1984 to 2011, which had gained a large following during that period. At an early age of 17, he had been a guitarist for Brazilian rock and MPB icons (e.g.; Raul Seixas, Sá e Guarabyra, and Luiz Melodia) and was best known for his hit, Aumenta que isso ai e rock'n'roll ("Play it louder, because that is rock'n'roll") released in his album, Som na Guitarra in 1984 (O Globo, 2012).
} 
Big Allambik, Nuno Mindelis, Companhia do Blues, Blue Jeans, Expresso 2222, Atlantico Blues, and Zé da Gaita, among several others.

By the early 1990s, several of these unsigned blues bands soon developed national name recognition marketed as "Brazilian blues artists."15 Some city venues began to integrate a few of these blues bands with other Brazilian artists and genres in Brazil. For example, the Blue Jeans trio had participated in an experimental show at a venue in São Paulo known as SESC Pompéia, with the late J.J. Jackson (born in the United States, and nationalized in Brazil, whose real name was Leo Robinson), and Brazilian singer-songwriter, Itamar Assunção, and featured in a performance named "Jazz and Blues Fusion." They also performed in a series of shows billed along with Arrigo Barnabé in 1992, which tried to incorporate blues with other musical genres of the Americas, in a series named, "Music of the Americas."

By 1992, another Brazilian blues band of importance, Big Allambik released, Blues Special Reserve (Big Allambik, 2020, https://www.allmusic.com/artist/big-allanbik-mn0001402419.). After they disbanded, its former members became well-established musicians with international recognition, such as Big Gilson (guitarist), Ugo Perrota (bass player, who has performed with Blues Etílicos, Blues Groovers, and Eric Gales, among others), and Beto Werther (current drummer for Blues Etílicos, and Blues Groovers) (Obvious Magazine, 2016). Both the keyboard player, Allan Green, and lead singer, Ricardo Werther (Beto Werther's brother) have since passed. After leaving Big Allambik, Ricardo Werther had moved on to launch a successful solo career in Rio, and his death was widely covered by the Brazilian press (See, Moreira, 2013).

Today, the list of names in this Brazilian blues scene is far more extensive, one which I do not discuss here since my focus has looked only at the genesis and diffusion phase of the phenomenon of blues in Brazil (1985-1992) - and not the current phase in Brazil. This phase after 1992, is a topic left wide open for scholars to examine in the future.

\footnotetext{
${ }^{15}$ For example, Nuno Mindelis released his first solo album in 1991 with Movieplay label, Long Distance blues. A few years later, in 1995, he released Texas Bound with Eldorado, with Chris Layton on drums and Tommy Shannon on bass (i.e.; known as "Double Trouble," the backing band for the iconic guitarist, Stevie Ray Vaughan). Today he is a touring blues artist with a wide following around the world (Nuno Mindelis, 2020, http://nunomindelis.com.br/v2/bio/). Marcos Ottaviano is another guitarist who gained national recognition. He had left the band, Companhia do Blues after a few stints with Celso Blues Boy in 1992, joined the power trio, Blue Jeans in 1993, releasing Come Back Home in 2004, with drummer, Junior Moreno, and bass player, Andrei Ivanovic. Ottaviano remained with the Blue Jeans for another 13 years, and then launched his solo career releasing albums and publishing books on blues techniques. Today he is recognized as a national bona fide blues guitarist (Marcos Ottaviano, 2020, https://www.marcosottaviano.com.br/). The band, Baseado em Blues, and its harmonica player, Jefferson Gonçalves, also merits attention here. Although they emerged in the final year of this study, Gonçalves has gone on to become one of the major figures in Brazilian blues.
} 


\section{The Post-Ribeirão Preto Blues Boom in Brazil}

Two years after the Ribeirão Preto blues festival, a Brazilian newspaper in São Paulo, Folha de São Paulo, published a full-page feature written by journalist, Luís Antônio Giron about the new blues boom in Brazil (Giron, 1991). Giron referred to the new blues bands as "bluesboys" who had invaded MPB to "steal" the space of rock, becoming a "summer fad" (moda de verão) - ostensibly dismissing the musical credibility of those new bands by labeling them as "boys" and by framing their interest in blues as a passing "summer fad" (André Christovam and Blues Etílicos were not considered "newcomers" by that time). Giron described how these 20-year-old white urbanite Brazilians were questioning the meaning of contemporary rock music and the new wave of Brazilian pop/rock and preferring to opt instead to playing blues. Giron pointed out how these musicians wanted to return to "roots music," and something more meaningful than the forgettable pop music of that period. ${ }^{16}$ The new Brazilian blues bands of this feature article were: Companhia Paulista de Blues, Blue Jeans, Spirit Blues, Expresso 2222, Blues Connection, Bauxita, and Blues Company. Seemingly, Brazilian-based musical genres such as lambada, samba, and other sub-genres, considered music of the povão, had less cultural cachet for these white urbanite Brazilian musicians.

This year of 1992 becomes a point of departure here, because after this year, most of those unsigned Brazilian blues bands would come to release their own albums and gain recognition in Brazil, and the phase of inception was over - after this year, audiences had already become exposed and familiar with the genre of blues. Blues Etílicos would release several other albums afterwards, influencing several dozens of new Brazilian blues bands who would emerge during that period (1985-1992), and consequently, spawning young blues fans and still influencing bands in Brazil today, even after 35 years together (as of November 2021) - they are the oldest existing Brazilian blues band in Brazil.

\footnotetext{
${ }^{16}$ In the same newspaper edition of that same day, December 20, just two pages ahead of this feature, another article appeared, Veteranos criticam blueseiros oportunistas ("Veterans criticize musicians who play blues and who are opportunists") written by journalist, Carlos Calado (Calado 1991). In an incongruous commentary, featuring André Christovam, who was only 33 years old then, Calado already considered him a "veteran bluesman." Christovam was interviewed, and centred his condemnation on Brazilian musician, Alceu Valença, categorically calling him an "opportunist" for recording a blues song in Portuguese. Christovam, the self-anointed and self-inflated "blues ambassador" in Brazil, disavowed any musician who in his mind, was not playing "real blues" as he was (or as he thought he was), as absurd as it sounds. Yet here was the case of a young white, middle-class, Brazilian urbanite musician, who gained press coverage for disparaging and policing fellow Brazilian musicians, with the intent of "schooling" them on blues music. That is, the same music of poverty-stricken African Americans worlds away from his universe and hubris, most of whom would likely find this scenario downright pretentious and petty, if not laughable. His media interviews to this day, still convey the same policing rhetoric. These kinds of disputes and the act of policing of "real blues" also occurs in Russia (See, Urban, 2004).
} 


\section{Spaces and Venues: The Dissemination of Blues}

The various spaces (venues) where blues diffused to young audiences in Brazil, included nightclubs such as Dama Xoc and Aeroanta (both closed decades ago) and Blue Note Bar (not affiliated to the U.S.-based Blue Note), in São Paulo, and Jazz and Blues (in Santo André, a municipality located on the outskirts of that city). Advertisements that I found in the Brazilian newspapers, Jornal do Brasil and Tribuna da Imprensa between 1986 to 1991, reflect how the Blues Etílicos performed at various venues, ranging from small bars to larger clubs, open concerts, and universities throughout the city of Rio (e.g.: Bar Pitéu, O Viro da Ipiranga, Let it Be, Made in Brazil, Duerê, Faculdade de Comunicação e Turismo, Circo Voador, Teatro Bertold Brecht do Planetário, People, Rival Theatre, and Perestroika - to name a few). Notably, as early as 1988, they were already performing for as many as 4,000 people at the Parque da Catacumba, 2,000 people in Praia de Icaraí (in Niterói, outside of Rio), and in the same year, opening for larger national acts such as Barão Vermelho at the Circo Voador. The press covered their shows leaving a trail of newspaper advertisements that attest to this geographical diffusion and expansion in the late 1980s. ${ }^{17}$ These examples show how the geographical spaces (venues) played a vital role in the diffusion process of the blues in Brazil.

Here the work of Connell and Gibson is useful to understand this gradual introduction of blues to Brazil, as they aptly state, "popular music is spatial" (2003, p.1). Furthermore, they point out how music can become a form of social control or a way to challenge social norms (2003, p.24). In this case, in all likelihood blues became popular among young Brazilians in the late 1980s and early 1990s, perhaps for the same reasons it was so popular white youth in the U.S. or Europe in the late 1960s, that is, for its association with the counterculture and rebellious inclinations (i.e.; antiestablishment, anti-dictatorship). That is, young audiences were challenging the social and musical norms during the Brazilian post-dictatorship phase in the late 1980s. In this context, especially during the later period of the military dictatorship, "Brazilians identified with and took inspiration from the international counterculture, or contracultura, as it is known in Brazil." (Dunn 2016, p.1).18

\footnotetext{
${ }^{17}$ Advertisements for venues and perfomances of the band Blues Etílicos duirng the late 1980s and early 1990s appeared in the following newspapers in Rio de Janeiro: "Público vibra com rock e blues na Praia de Icaraí" $O$ Fluminense, January 16, 1990, 3; Pedro Tinoco. "Triste, eterno e etílico." Tribuna da Imprensa, November 17, 1988, 1; Bar Pitéu (Rua Prof. Ferreira da Rosa 130) Tribuna da Imprensa, Rio de Janeiro, October 9, 1987, 4; O Viro da Ipiranga (Rua Ipiranga 54), Jornal do Brasil, April 11, 1986, 5; Let it Be (Rua Siqueira Campos 206) Jornal do Brasil, Feb 7, 1986, 5; Made in Brazil (Av. Armando Lombardi 1000, Barra), Jornal do Brasil, July 27, 1986; Duerê (Estrada Caetano Monteiro 1882, Pendotiba), Estado do Rio de Janeiro, Niterói, December 8, 1988; Faculdade de Comunicação e Turismo, Hélio Alonso (Rua Muniz Barreto 51) Jornal do Brasil March 20, 1987; Planetário da Gávea. Jornal do Brasil, April 4, 1987, 6; Teatro Bertold Brecht do Planetário (Av. Padre Leonel Franca 240) Jornal do Brasil, April 24, 1987; People (av. Bartolomeu Mitre 370) Jornal do Brasil, 1988, April 6.

${ }^{18}$ For a more nuanced and sophisticated discussion on Brazilian counterculture in the 1960s and 1970s (contracultura), see Dunn 2016.
}

ßRASILIANA: Journal for Brazilian Studies. ISSN 2245-4373. Vol. 10 No. 2 (2021). 
That is, young Brazilian urbanites had made several personal lifestyle changes during the 1970s, as Christopher Dunn, explains, "for some children of privilege, countercultural exploration provided a way to free themselves of stifling family ties, parental expectations, and financial dependency." (Dunn 2016, p.44).

The popularity of blues was also symptomatic of audiences who were reacting negatively to the prominent Anglo-American electronic/pop and New Wave bands of the Reagan/Thatcher Era (e.g.; The Cure, Depeche Mode, Flock of Seagulls, Duran Duran, etc.). Hence, the high demand for blues (particularly live performances of blues bands) because of the dissatisfaction with Brazilian rock and international pop bands of that time, and the sociocultural, political, and economic shifts of that period, dovetailed with the rise and popularity of the band, Blues Etílicos, and moreover, contributed to the overall diffusion of blues in Brazil.

\section{Conclusion}

Here I have only focused on the period between 1985 and 1992, however, the blues movement in Brazil has remained in the shadows of the Brazilian music industry, and never went mainstream (i.e.; "indigenized") like it did in Britain during the 1950s and 1960s. Nonetheless, a clear detectable presence of Brazilian artists and bands performing abroad has emerged.

This discussion of the Geography of music, the diffusion of blues worldwide, and the diffusion of blues to, and within Brazil, combined, help to shed light on how the blues became popularized in Brazil, despite the fact that the genre never became part of mainstream Brazilian music.

This article discussed: (1) The vital role of spaces, venues, audiences at live performances mostly in the core cities of Rio and São Paulo; (2) Vital blues Brazilian bands such as Blues Etílicos (Brazil's oldest existing blues band) who carried out the musical integrity of the blues tradition and helped popularize and diffuse the blues genre in Blues, and; (3) The importance of blues festivals in the process of boosting the diffusion of blues within Brazil, such as Brazil's first blues festival in Ribeirão Preto in 1989.

To the rest of the world, Brazilian blues musicians, as studious ethnomusicologists of blues, may be unfairly perceived as some sort of "exotic oddity"- largely considered a phenomenon merely resting on the periphery of world music landscapes - perhaps without receiving the musical and professional credibility that they deserve. However, it is improbable and unlikely that they will ever belong to the core musical spheres akin to the "British blues scene" that had once catapulted a pantheon of British blues guitar icons in the 1960s into world prominence. The blues was not 
indigenized in Brazil as it was in Britain. That is, the British cultural and musical phenomenon of the 1960s occurred during a specific historical period aligned with its respective cultural, musical, and political contingencies of that time.

Here I also offer a springboard for future researchers who may want to examine the blues in Brazil today (after 1992). Given the wide geographical span of existing Brazilian blues venues and several dozens of blues bands in virutally every Brazilian state, therefore, more academic research is needed to understand the contemporary phenomenon of blues in Brazil. The types of subsequent academic research on this topic would benefit by asking questions such as: What happened to the blues scene in Brazil since 1992? What is the blues market and blues audience demographic in Brazil today?

Ostensibly by 1992, and much to their chagrin, Brazilian blues musicians ultimately remained constricted to being merely "Brazilians" (i.e.; white, middle-and-upper-class Brazilian urbanites).from the land of Samba, Lambada, and Bossa Nova, relegated to the global musical periphery and perpetually striving to play a musical genre of poverty-stricken African-Americans located worlds away.

\section{References}

Adelt, U. (2010). Blues Music in the Sixties: A Story in Black and White. NJ: Rutgers University Press.

Alderman, J. (2001). Sonic Boom. Napster, MP3, and the New Pioneers of Music. Foreword by E. I. Schwartz, Preface by H. Hancock. Cambridge, Massachusetts: Perseus Publishing.

Bellos, A. (2005). 'Baile funk might be the most exciting music in the world - it certainly comes from one of its most dangerous places.' The Guardian, September 17, https://www.theguardian.com/music/2005/sep/18/brazil.popandrock (Accessed March 20, 2020).

Big Allambik (2020). Available at: https://www.allmusic.com/artist/big-allanbik-mn0001402419 (Accessed March 20, 2020).

Blues'n' Jazz Brasil (2020), https://bluesnjazz.com.br/web/ (Accessed March 20, 2020).

Brandellero, A. M. C., and Pfeffer, K., (2011). Multiple and Shifting Geographies of World Music Production. Area, 43 (4), p.495-505.

Brazilian Federal Government. Presidency of the Republic of Brazil (2020a). 'Brazilian music market grew $18 \%$ after ten years of recession,' http://www.brazil.gov.br/arts-culture/music/brazilian-music-marketgrew-18-after-ten-years-of-recession (Accessed March 20, 2020).

Brazilian Federal Government. Presidency of the Republic of Brazil (2020b). 'Brazil has Festivals for All Tastes.' http://www.brazil.gov.br/arts-culture/music/Brazil-has-festivals-for-all-tastes-Check-out-a-fewhighlights (Accessed March 20, 2020).

Brocken, M. (2003). The British Folk Revival 1944-2002. London: Ashgate. 
Calado, C. (1991). 'Veteranos criticam blueseiros oportunistas.' Folha de São Paulo, December 20, 1991, 3.

Connell, J. and Gibson, C. (2003). Sound Tracks. Popular Music, Identity and Place. London \& NY: Routledge.

Dunn, C. (2001). Brutality Garden: Tropicalia and the Emergence of a Brazilian Counterculture. Chapel Hill: The University of North Carolina Press.

Dunn, C. (2016). Contracultura: Alternative Arts and Social Transformation in Authoritarian Brazil. Chapel Hill: The University of North Carolina Press

Ford, L. (1971). Geographic Factors in the Origin, Evolution, and Diffusion of Rock and Roll Music. Journal of Geography, (70)8, p.455-464.

Frame, P. (2007). The Restless Generation. How Rock Music Changed the Face of 1950s Britain. London: Rogan House.

Gioia, T. (2008). Delta Blues: The Life and Times of the Mississippi Masters who Revolutionized American Music. NY: W.W. Norton and Company.

Giron, L. C. (1991). 'Bluesboys invadem MPB, roubam espaço do rock e viram moda de verão.' Folha de São Paulo, December 20, 1991, 1.

Goldsmith, M. U. D. and Fonseca, A. J. (Eds.) (2019). Hip Hop Around the World: An Encyclopedia. Santa Barbara, California, and Denver, Colorado: Greenwood.

Grossberg, L. (1992). We Got to Get Out of This Place: Popular Conservatism and Postmodern Culture. NY: Routledge.

IFPI (2020). 'Representing the Recording Industry Worldwide, Brazil: A top performing market.' Accessed March 20, 2020, https://www.ifpi.org/brazil.php and https://www.ifpi.org/consumer-research.php (Accessed March 20, 2020).

Johansson, O. and Bell, T. L. (2009). Sound, Society and the Geography of Popular Music. Surrey, UK: Ashgate.

Júnior, E. M. (2009). 'Mandinga Blues.' Available at: https://mandingablues.wordpress.com/o-blues-no-brasil/ (Accessed March 20, 2020).

Kruse, H. (2003). Site and Sound: Understanding Independent Music Scenes. NY: Peter Lang.

Kruse, H. (2010). 'Local Identity and Independent Music Scenes, Online and Off.' Popular Music and Society, 33(5), p.625-639.

Lima, E. S. (1989). 'Com Blues na Veia.' Jornal do Brasil, April 14, 1.

Making a Scene, The Independent Music Magazine (2020). 'Selling the Blues' first published on August 28, 2015, Available at: https://www.makingascene.org/selling-the-blues/ (Accessed March 20, 2020).

Mandinga Blues (2020). Available at: https://mandingablues.wordpress.com (Accessed March 20, 2020).

Marcos Ottaviano (2020). Available at: https://www.marcosottaviano.com.br/ (Accessed March 20, 2020).

Marcus, A. P. (2020). Skiffle in the U.K.: The Indigenization of a Musical Genre. Journal of Cultural Geography 37 (2), p. 216-235.

Marcus, A. P. (2013). Sex, Color, and Geography: Racialized Relations in Brazil and its Predicaments. Annals of the Association of American Geographers 103(5), p.1282-1299.

McCann, B. (2007). Blues and Samba: Another Side of Bossa Nova History. Luso-Brazilian Review, (2), p.21-49.

ßRASILIANA: Journal for Brazilian Studies. ISSN 2245-4373. Vol. 10 No. 2 (2021). 
Mello, J. (2012). 'The Brazilian Music Industry. The Brazil Business.' November 21, 2012. Available at: https://thebrazilbusiness.com/article/the-brazilian-music-industry (Accessed March 20, 2020).

Mississippi Delta Blues Festival, Caxias do Sul, Rio Grande do Sul (2020). Available at: https://mdbf.com.br (Accessed March 20, 2020).

Moreira, M. (2013). 'A voz do blues carioca foi embora - um adeus a Ricardo Werther." Estado de São Paulo, February 19, 2013. Available at:_https://cultura.estadao.com.br/blogs/combate-rock/a-voz-do-bluescarioca-foi-embora-um-adeus-a-ricardo-werther/ (Accessed, March 20, 2020).

Nuno Mindelis. (2020). Available at: http://nunomindelis.com.br/v2/bio/ (Accessed, March 20, 2020).

Obvious Magazine (2016). 'Blues no Brasil.' Available at:

http://obviousmag.org/viver_a_deriva_e_sentir_que_tudo_esta_bem/2016/blues-no-brasil.html (Accessed March 20, 2020).

O Globo. (2012). ‘Morre músico Celso Blues Boy aos 56 Anos.' O Globo, August 6, 2012. https://oglobo.globo.com/cultura/morre-musico-celso-blues-boy-aos-56-anos-5702995. (Accessed March 20, 2020).

Palmer, R. (1981). Deep Blues: A Musical and Cultural History from the Mississippi Delta to Chicago's South Side to the World. NY: Penguin.

Perrone, C. A. and C. Dunn (2002). 'Chiclete com Banana': Internationalization in Brazilian Music.' In Brazilian Popular Music \& Globalization, C. A. Perrone and C. Dunn (eds), pp.1-38. 2002. NY: Routledge,

Perrone, C. A. and Dunn C. (Eds.) (2002). Brazilian Popular Music \& Globalization. NY: Routledge.

Poiger, U. G. (2000). Jazz, Rock and Rebels. Cold War Politics and American Culture in a Divided Germany. Berkeley: University of California Press.

Strait, J. B., and Fujimoto-Strait, A. R. (2017). 'The Impact of Multi-Layered Diffusionary Processes on Musical Evolution: The Global Nature, and Hawaiian, Spanish and African Roots of Delta Music Culture.' European Scientific Journal, October 2017, Special Edition, p.257-276.

Stratton, J., (2010). 'Skiffle, Variety and Englishness.' In Britpop and the English Music Tradition, pp. 27-40, A. Bennett and J. Stratton, Eds., Surrey, U.K.: Ashgate.

Stroud, S. (2016) [2008]. The Defence of Tradition in Brazilian Popular Music. Politics, Culture and the Creation of Música Popular Brasileira. NY: Routledge.

Terra Blues. (2020). 'Blues Publications.' Available at: https://www.terrablues.com/bluespublications.html (Accessed March 20, 2020).

The Blues Foundation (2020). Available at: https://blues.org/affiliate-map (Accessed March 20, 2020).

The Blues Foundation (2020). Memphis, Tennessee, Available at: https://blues.org/about/\#mission (Accessed March 20, 2020).

Urban, M. with A. Evdokimov (2004). Russia Gets the Blues: Music, Culture, and Community in Unsettled Times. Ithaca and London: Cornell University Press.

Wallach, J., H. M. Berger, and Greene, P. D. (eds) ( 2011). Metal Rules the Globe. Heavy Metal Music Around the World. Durham: North Carolina, Duke University Press.

BrasiluanA: Journal for Brazilian Studies. ISSN 2245-4373. Vol. 10 No. 2 (2021). 
Zantige, A. (2015). 'Not the same old blues. Brazil gets the blues in its own, unique way.' Wall Street International Magazine. March 14, 2015. https://wsimag.com/entertainment/13725-not-the-same-old-blues (Accessed March 20, 2020). 